BEATA WOZIWODA $^{1} \&$ KATARZYNA AMBROŻKIEWICZ $^{2}$

${ }^{1}$ Department of Geobotany and Plant Ecology, University of Lodz, Banacha 12/16, 90-237 Lódź, Poland, woziwoda@biol.uni.lodz.pl

${ }^{2}$ Gladka 12/20, 93-378 Łódź, Poland, k_ambrozkiewicz@wp.pl

\title{
DIVERSITY OF FOREST AND SHRUB COMMUNITIES AS A RESULT OF SITE HISTORY AND OF EXTENSIVE AND INTENSIVE FOREST MANAGEMENT (GLINNO ŁUGI CASE STUDY)
}

\begin{abstract}
The paper presents the diversity of natural and anthropogenic forest communities occurring in post-cultivated fields in Glinno Ługi. An impoverished fresh pine forest association (Leucobryo-Pinetum) and nine secondary forest communities have been distinguished in the transect line (1.16 km in length). Factors influencing the structure and species composition of recent forest communities, such as habitat properties, previous land use forms and the intensity of forest management, are described.
\end{abstract}

Key words: land use, abandoned arable fields, afforestation, succession of vegetation, Scots pine, Central Poland

\section{INTRODUCTION}

Abandonment of farmlands on the poorest soils is one of the symptoms of socio-ecological changes taking place in the Polish countryside at present. Formerly cultivated fields have usually been artificially afforested with Scots pine (GORZELAK 1999). Land use history, as well as habitat conditions and the intensity of forest management can have a large effect on the species composition of secondary forest communities (Grashof-BoKdam, GeERTSEMa 1998; DzWONKo, LOSTER 2001; ZERBE et al. 2007). The conversion of anthropogenic forests into natural ones has 
become a major task of European forestry (ZERBE 2002). The recognition as well as maintenance and enhancement of biological diversity in anthropogenic forests are one of the prerequisites for sustainable forest management.

In this study we investigated the floristic composition and structure of plantations and natural forests occurring in abandoned arable fields in Glinno Ługi near the Warta River.

\section{MATERIAL, METHODS AND STUDY AREA DESCRIPTION}

Phytosociological studies of forest vegetation were conducted in 2008 in the Glinno Ługi area. The study area is situated about $3 \mathrm{~km}$ east of the "Jeziorsko" water reservoir (Fig. 1). It is located in the eastern part of the Sieradzka Basin mesoregion (Kondracki 2002).

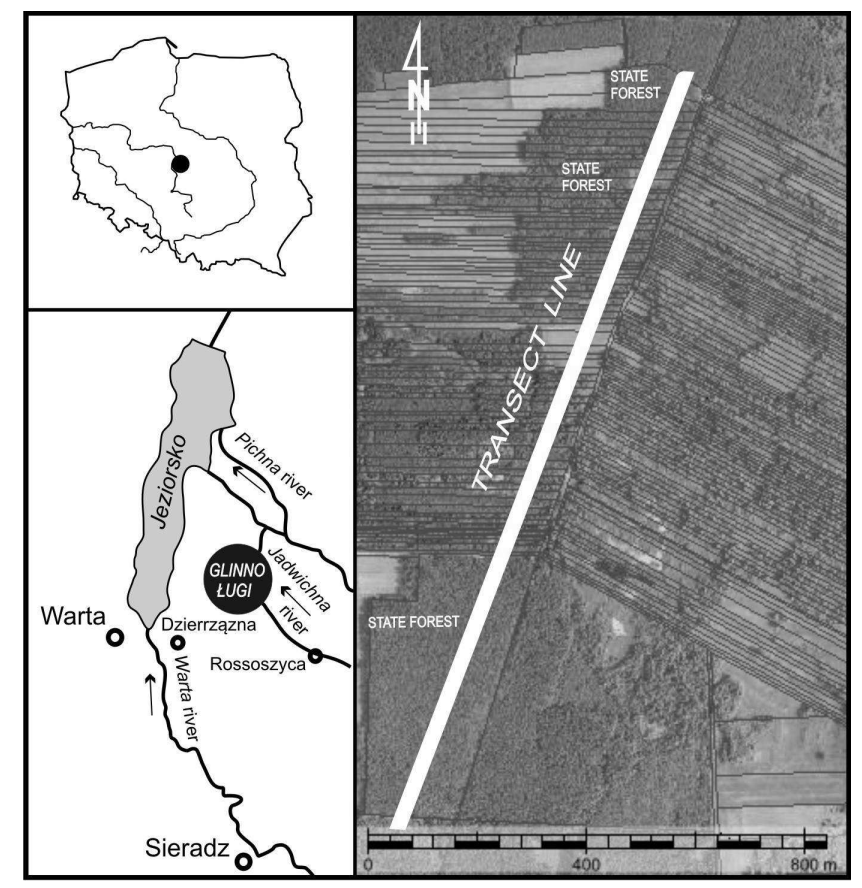

Fig. 1. Location of the study area and of the transect line.

The analysis of 32 phytosociological relevés was made according to the Braun-Blanquet approach. The sequence of forest communities was studied with the transect method. The transect line was $1160 \mathrm{~m}$ in length and $20 \mathrm{~m}$ in width, and it 
ran through sandy dunes and a local topographic depression, in the direction from the south-west $\left(51^{\circ} 43^{\prime} 38^{\prime \prime} \mathrm{N}\right.$ and $\left.18^{\circ} 42^{\prime} 25^{\prime \prime} \mathrm{E}\right)$ to the north-east $\left(51^{\circ} 44^{\prime} 21^{\prime \prime} \mathrm{N}\right.$ and $18^{\circ} 42^{\prime} 52^{\prime \prime}$ E; Fig. 1). It cut through forest patches differing in terms of tree stand age and composition. The larger part of this area had been artificially afforested. Some abandoned arable fields have successively overgrown with shrubs and trees. Most of the narrow (10 or 20 metres wide) plots are private properties. The southern segment of the transect line and a few patches in the north are located in state-owned woodlands. The borders of properties are determined by forest roads and field tracks.

The nomenclature adopted for vascular plants follows MIREK et al. (2002), for bryophytes - OCHYRA et al. (2003) and SZWEYKOWSKI (2006).

\section{RESULTS}

The results of the phytosociological studies are presented in Table 1. Figure no. 2 shows the sequence of the forest communities distinguished.

\subsection{Description of forest communities}

A fresh pine forest (Leucobryo-Pinetum) association and a Scots pine community closely resembling sub-Atlantic mesic pine forest (Tab. 1, columns: 1-11). The areas with the habitat of oligotrophic coniferous forests are forested mostly by Scots pine Pinus sylvestris. The currently mature, single-species tree stand was planted 70-90 years ago in what was then a clearing. Separate patches of this fresh pine forest community display a large diversity as regards the species composition of the undergrowth and herb layer.

The physiognomy, vertical structure and species composition of the patches with the oldest pine tree stand (over 80 years old) are close to those of natural fresh pine forest. These patches are described as an impoverished regeneration form of a Leucobryo-Pinetum association. They are characterized by the presence of acidophilous species associated with coniferous forests, such as Vaccinium myrtillus, Calluna vulgaris, Festuca ovina. The layer of cryptogams is conspicuous and forms a carpet covering of up to $100 \%$ of the patch. It is dominated by species 
characteristic of the Vaccinio-Piceetea class such as Dicranum scoparium, D. polysetum and Pleurozium schreberi.

The other patches have better developed undergrowth. The shrub layer is built mainly by Frangula alnus and Sorbus aucuparia. Padus serotina, which is an alien species, occurs almost everywhere (both in the undergrowth, and in the herb layer). Another foreign species, Quercus rubra, grows only in the southern part of the transect. The herb layer is usually less diverse than the moss layer. Agrostis stolonifera and Dryopteris carthusiana are frequently noticed in the relevés. In some patches, the ground cover is dominated by Calamagrostis epigejos, which occupies up to $3 / 4$ of the area. Different species of bryophytes cover from $5 \%$ to $95 \%$ of the patch area. Pleurozium schreberi and Pohlia nutans appear commonly.

Young monocultures of Pinus sylvestris (Tab. 1, columns: 12-19). In the analyzed phytocoenoses, the tree stand is highly well-stocked (70-90\%). The Scots pine grows on poor sandy arable fields excluded from agriculture. Most of the patches lack developed undergrowth and the herb layer is very sparse or there are no herb species altogether. However, young individuals of Quercus robur, Frangula alnus and the invasive Padus serotina occur on almost every patch. Bryophyte coverage is diverse and extends from 3\% to 50\%. Only Sciuro-hypnum oedipodium is noted everywhere. It is interesting to note the occurrence of mosses associated with natural coniferous forests (Vaccinio-Piceetea) such as Pleurozium schreberi and Dicranum scoparium.

Young plantations of Pinus sylvestris and Betula pendula (Tab. 1, columns: 20-23). Patches of this community are located on the top of a sandy dune. Scots pines and silver birches were planted together, but the Betula pendula trees are dying because of a water shortage. The herb layer is poorly developed. Vascular plants occur mainly in the microhabitats in the shade of trees. Species characteristic of seminatural and anthropogenic communities, such as Rumex acetosa, $R$. acetosella, Agrostis stolonifera, Convolvulus arvensis and Knautia arvensis, are more widespread. The moss layer covers from $15 \%$ to $60 \%$ and it is built both by mesophilous (Pleurozium schreberi) and thermo- and xerophilous species (Polytrichum juniperinum, P. piliferum). 

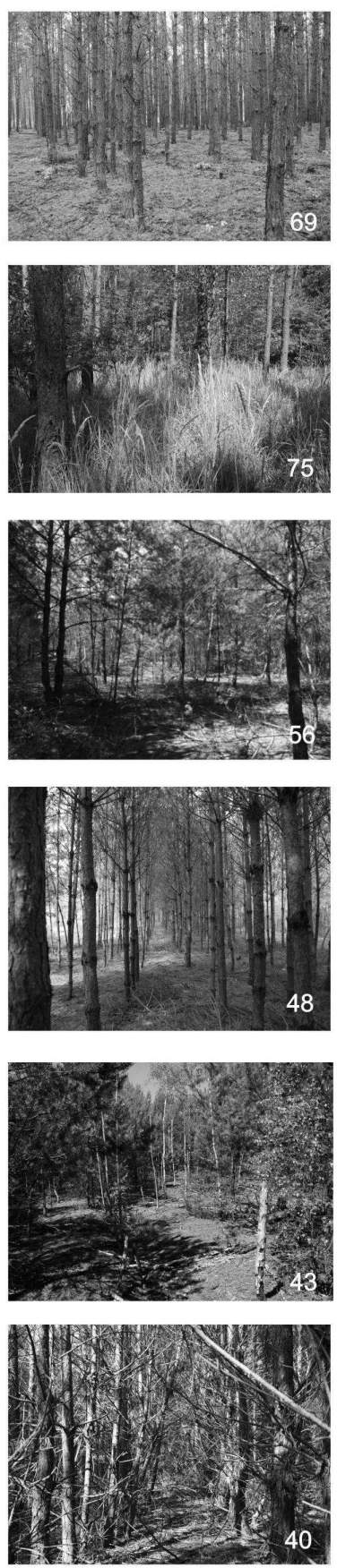

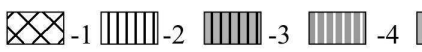
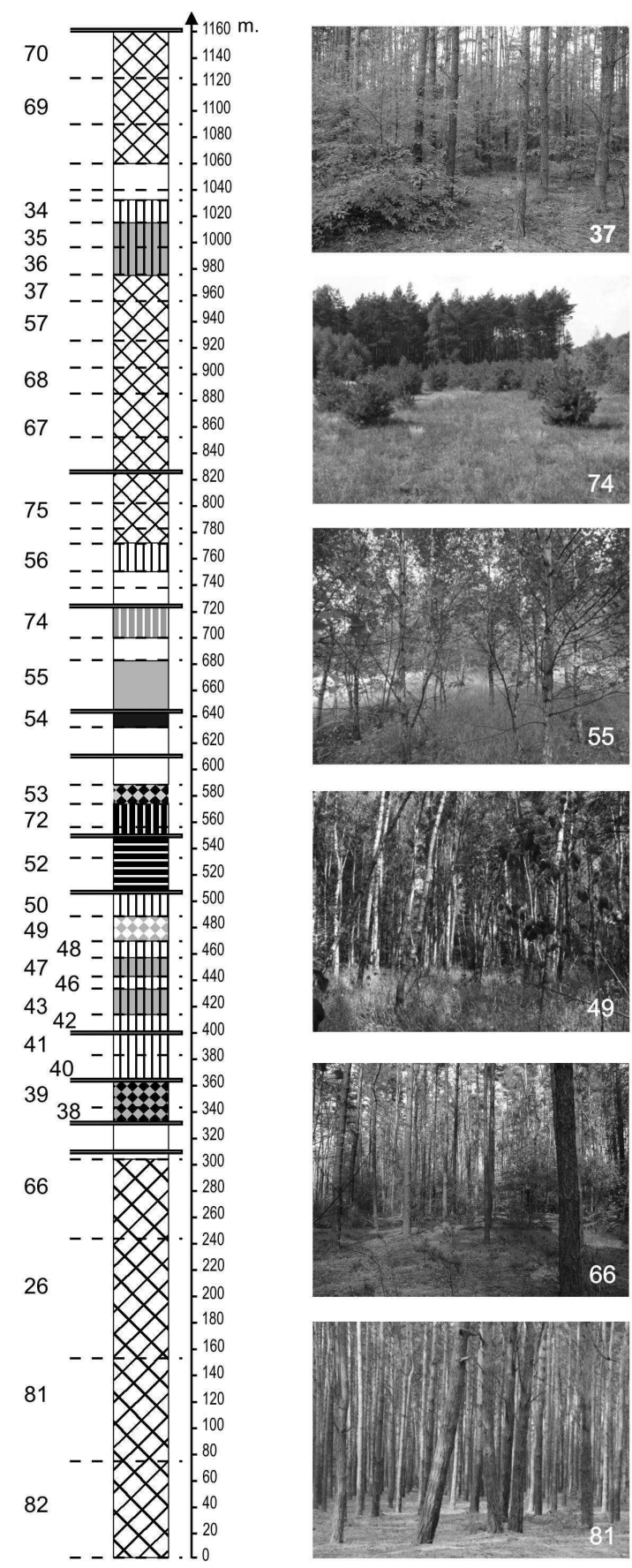

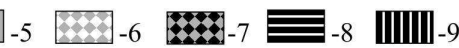
$---12=-13 \quad 82-14$

Fig. 2. Sequence of diverse plant communities along the transect line in Glinno Eugi. Explanation: 1 - fresh pine forest (Leucobryo-Pinetum) and Scots pine community close to the fresh pine forest, 2 - young monocultures of Pinus sylvestris, 3 - young plantations of Pinus sylvestris and Betula pendula, 4 - thickets of Pinus sylvestris, 5 - thicket of Betula pendula, 6 - Betula pendula-Holcus mollis community, 7 - mixed tree stand of Betula pendula and Populus tremula, 8 - Alnus glutinosa-Rubus sp. community, 9 - willow brushwood, 10 - plantation of Alnus glutinosa and Picea abies, 11 - ecotone zones, 12 narrow tracks, 13 - forest $\&$ field tracks, 14 - relevé number. 
Thickets of Pinus sylvestris (Tab. 1, column 24) developed naturally in a succession process on acid, sandy soils. It is a typical habitat of xerophilous and thermophilous grassland communities of the Koelerio-Corynephoretea class, occasionally and extensively used as a pasture for cattle. The young, widely-spaced pine individuals spread into the area from the adjacent 80-year-old Scots pine plantation. The further from the border of the mature tree stand, the lower the shrub density. The herb layer is floristically rich, built by species characteristic of the Koelerio-Corynephoretea class such as Corynephorus canescens, Jasione montana and Helichrysum arenarium, all of which grow plentifully. Species associated with arable fields (the Stellarietea mediae class) are also commonly noted, for example Conyza canadensis, Atriplex patula, Fallopia convolvulus, Raphanus raphanistrum and Setaria viridis. The sparse moss layer is built by only two species: Brachythecium rutabulum and Ceratodon purpureus.

A thicket of Betula pendula (Tab. 1, column 25). This forest community is situated in the immediate neighbourhood of a psammophilous grassland community of the Koelerio-Corynephoretea class. The tree stand is built by Betula pendula, planted in straight rows. The herb layer is dominated by species characteristic of Molinio-Arrhenatheretea, such as Deschampsia caespitosa, Elymus repens or Holcus lanatus. There also occur species characteristic of the KoelerioCorynephoretea class, for example Corynephorus canescens and Helichrysum arenarium. The bryophyte layer is really poor.

A Betula pendula-Holcus mollis community (Tab. 1, column 26). The anthropogenic tree stand is built exclusively by silver birch Betula pendula, at a density of $70 \%$. Frangula alnus, Pinus sylvestris and Betula pendula occur sporadically in the undergrowth. The main components of the dense herb layer are grasses such as: Holcus mollis, Festuca ovina, Anthoxanthum odoratum and Agrostis stolonifera. The moss layer covers $20 \%$ of the relevé area and it is made up mainly of Sciuro-hypnum oedipodium and Brachythecium rutabulum.

A mixed tree stand of Betula pendula and Populus tremula (Tab. 1, columns: 27-29). The silver birches and common aspens were planted on abandoned arable fields. At present they also build the undergrowth and spread spontaneously 
into the adjacent Scots pine monocultures. The herb layer is dominated by grass and sedge species characteristic of the Molinio-Arrhenatheretea class, such as Juncus effusus, Carex hirta and Agrostis stolonifera. Ruderal species of the Artemisietea class are also frequently noted. The coverage of moss layers, dominated by Brachythecium rutabulum, extends from $10 \%$ to $30 \%$.

An Alnus glutinosa-Rubus sp. community (Tab. 1, column 30). This anthropogenic phytocoenosis occupies a local depression situated between sandy dunes. The tree stand is built by even-aged black alders. Betula pendula and Betula pubescens occur in admixture. The undergrowth contains among others Sambucus nigra, Frangula alnus, Padus serotina and Salix cinerea. A significant area - about 3/4 of the patch - is occupied by blackberries Rubus sp.. The species composition of the herb layer is quite diverse and it includes 25 vascular plant species. Clumps of Urtica dioica and tussocks of Phragmites australis dominate. The local wet shallows are partially overgrown with nitrophilous species associated with the Bidentetea tripartiti class such as Rorippa palustris and Polygonum hydropiper. The bryophyte layer is very weakly developed.

A willow brushwood (Tab. 1, column 31) is located on the edge of the local depression in the neighbourhood of the alder tree stand. The dense thickets are formed by large gray willow Salix cinerea with a little admixture of eared willow Salix aurita and single specimens of white birch Betula pubescens. The herb layer is built by hygrophilous species such as Lycopus europaeus and Solanum dulcamara (the Alnetea glutinosae class), Deschampsia caespitosa, Lysimachia vulgaris, Myosotis palustris (Molinio-Arrhenatheretea), Galium palustre, Peucedanum palustre and Scutellaria galericulata (Phragmitetea). The share of mosses in the species composition is small. Among the 6 noted bryophytes only Calliergonella cuspidata reaches higher coverage.

A plantation of Alnus glutinosa and Picea abies (Tab. 1, column 32). The Norway spruce Picea abies and black alder Alnus glutinosa build a dense tree stand and undergrowth. The herb layer is weakly developed due to the deep shade on the forest floor. Only Holcus lanatus and Urtica dioica, which occupy up to $10 \%$ of the investigated area, reach a significant coverage. There are 12 moss species noted 


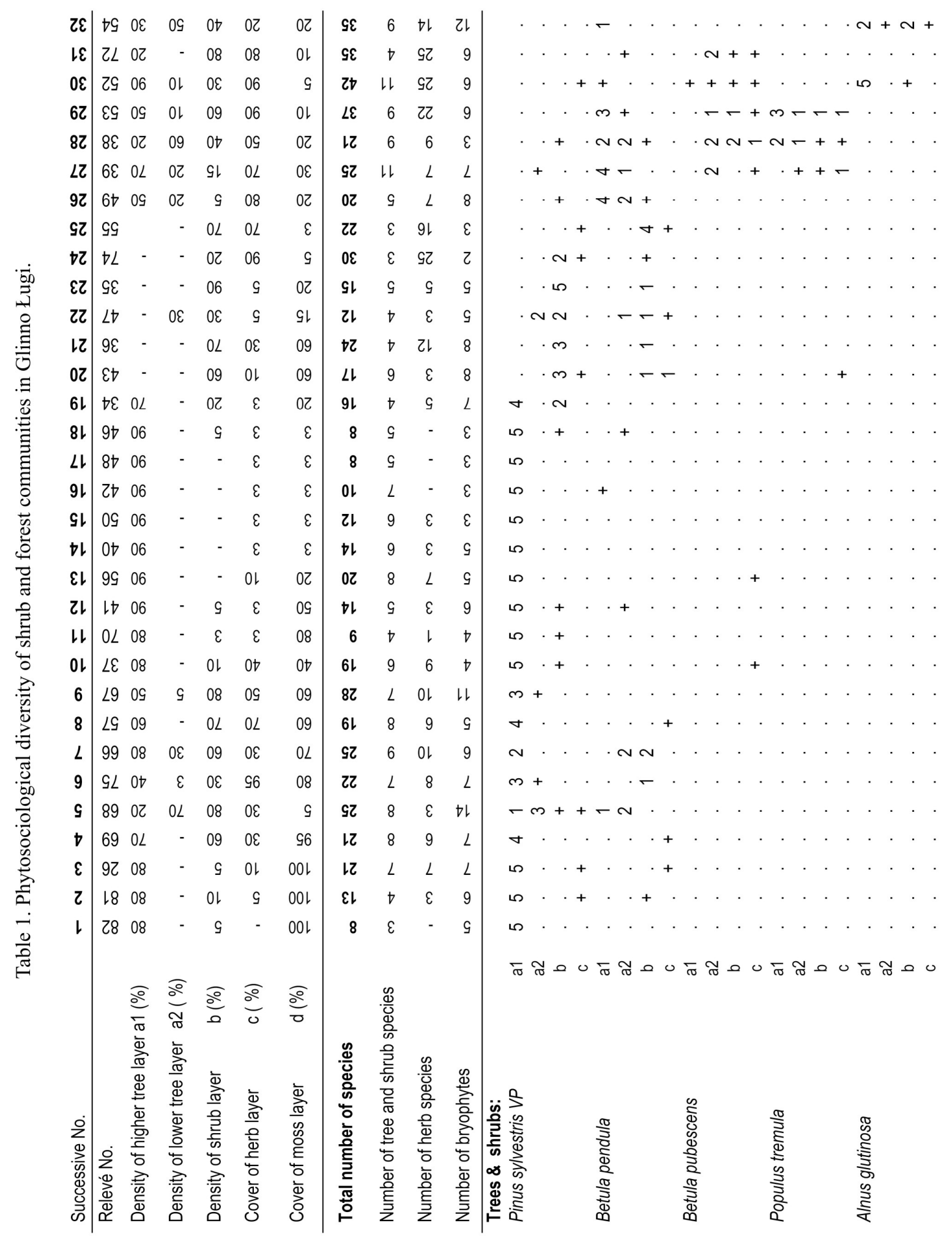



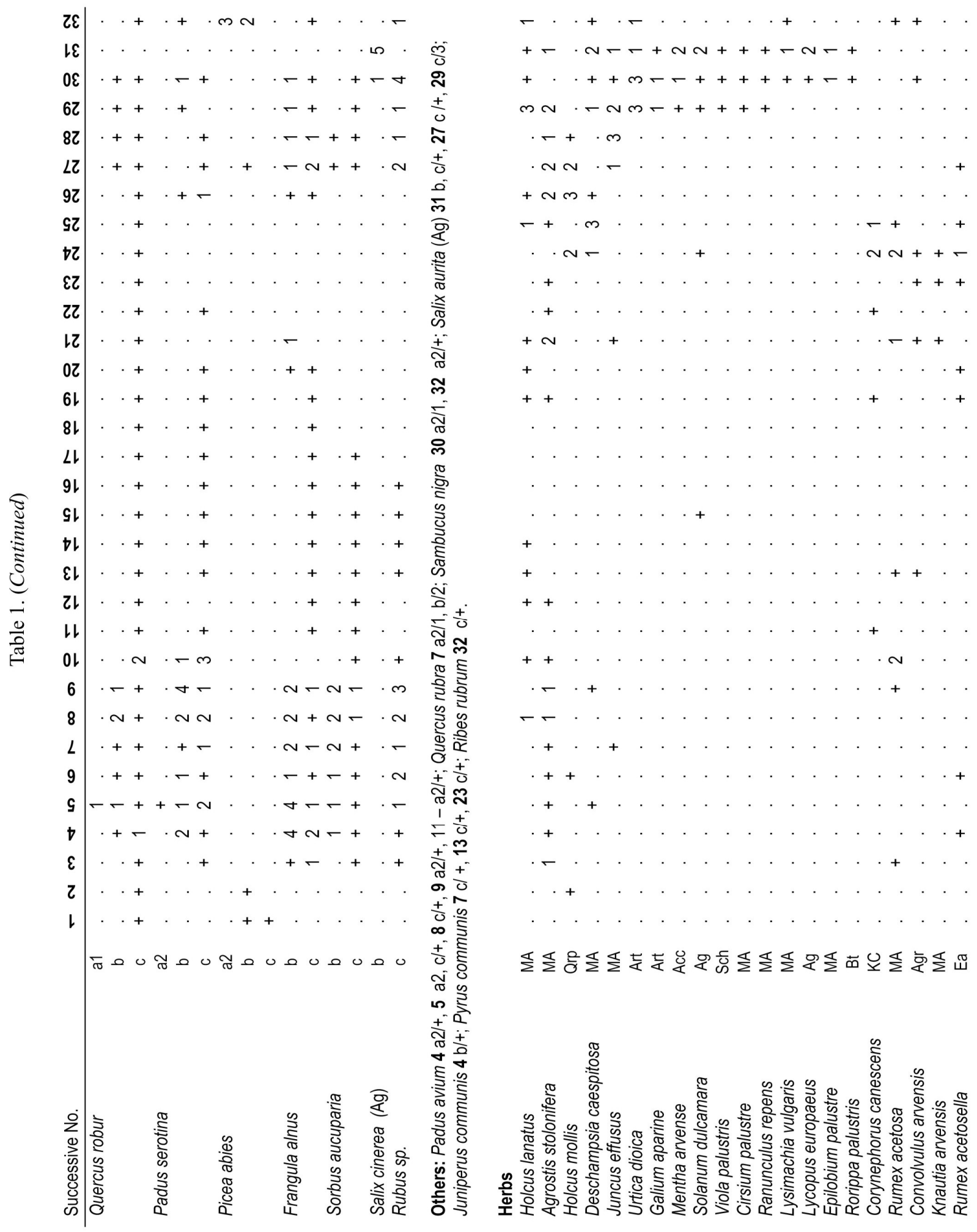


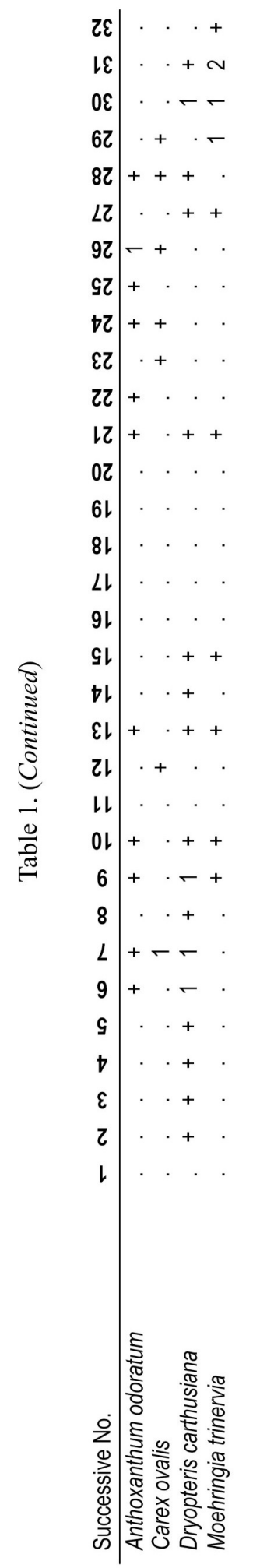

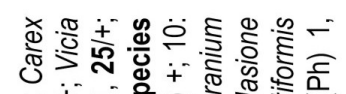

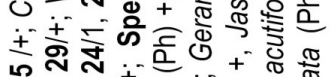

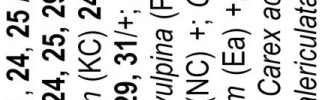

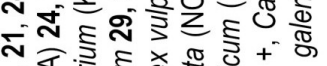

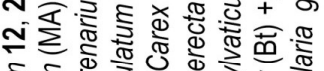

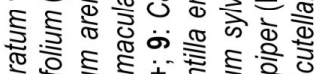

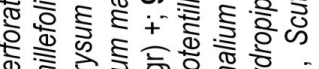

क्ष है

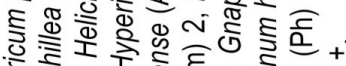

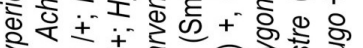

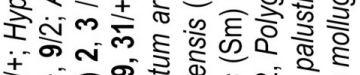

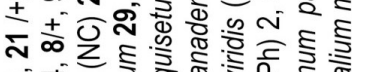

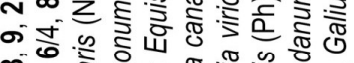

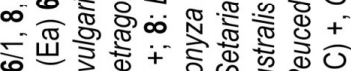

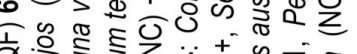

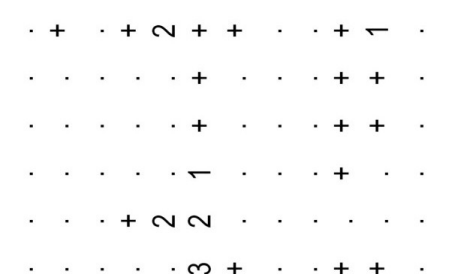

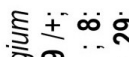

要更

है

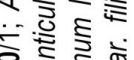

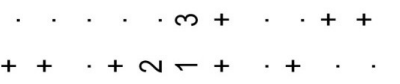

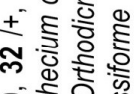

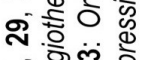

సัष

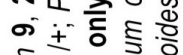

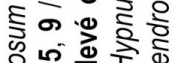

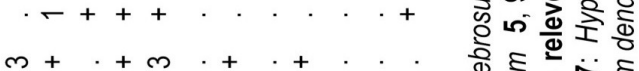

ब्षे

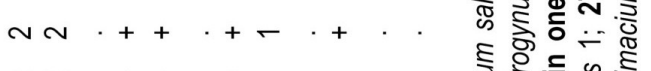

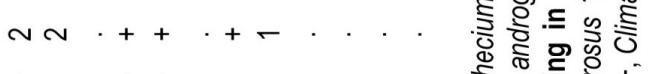

क

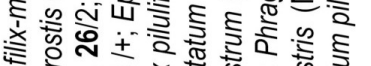

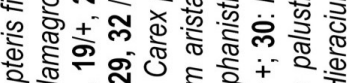

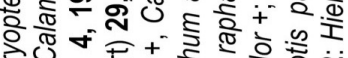

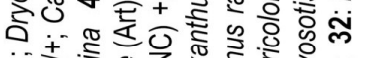

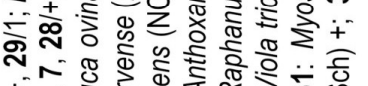

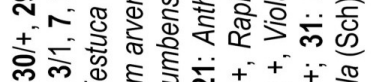

$$
+
$$

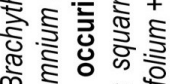

का
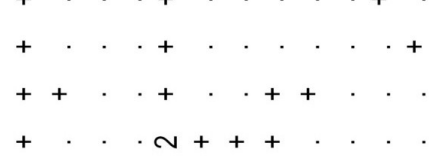

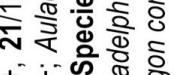

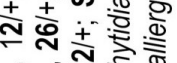

雨西足

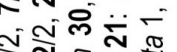

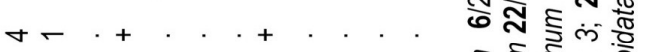

N. . . . . . . . . .

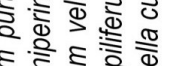

मू

. . . . +

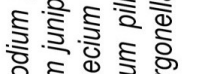

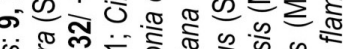

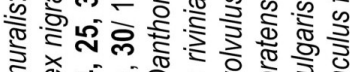

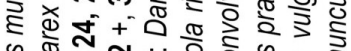

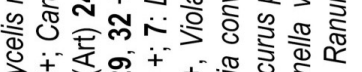

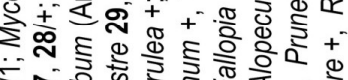

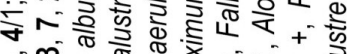

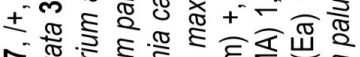

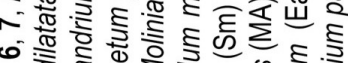

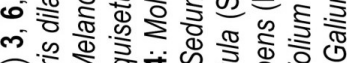

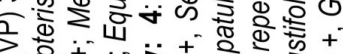

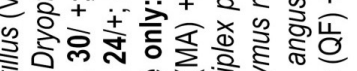

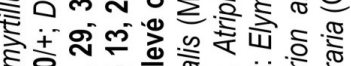

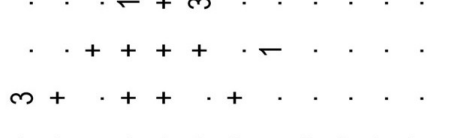

$++++++++++$

ம $\mathrm{N}++\cdot \cdot \cdot+\cdot \cdot \cdot+$

n $N m+$

$\checkmark N m+$

$\forall m m+$

s s s

원웡

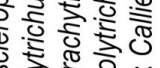

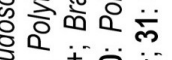

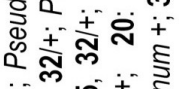

† 0 -

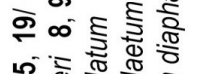

î.

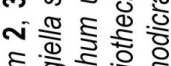

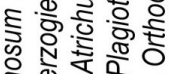

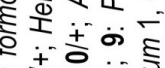

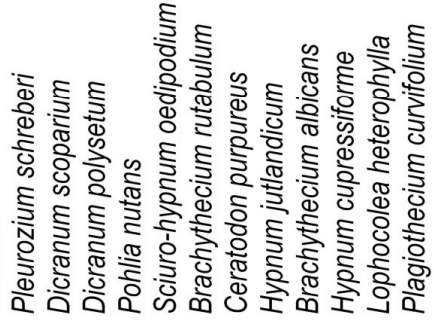

हิำ

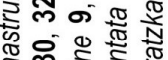

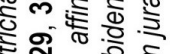

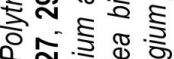

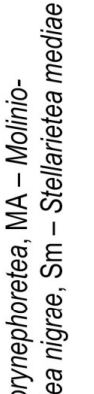


on the ground, stumps and on the lowest parts of the trees' trunks. Sciuro-hypnum oedipodium dominates.

\section{DISCUSSION AND CONCLUSIONS}

One impoverished fresh pine forest association (Leucobryo-Pinetum) and nine secondary forest communities have been distinguished in the transect line in Glinno Ługi. The tree stands and thickets of Scots pine are dominant and they cover more than $70 \%$ of the transect line area. The silver birch forest patches, the young tree-stands of Betula pendula and the poplar forest cover about 10\%. The anthropogenic monoculture of black alder and the spontaneous willow brushwood overgrow only the local wet depression (about $6 \%$ of the investigated patches) with thin peat deposit. The road lines, forest division lines and narrow ecotone zones (edges of plantations and tracks) are a significant part of the transect line - they constitute as much as $14 \%$. It is the result of intensive fragmentation of this area among many owners and the ensuing necessity to clearly outline borders in the landscape.

The sequence, tree stand composition and area of the forest communities reflect the areas of private properties and their borders. Land use forms and their intensity are different and depend on the local needs of field owners. The tree stand composition is determined by forest management, extensive in the majority of private forests and intensive in state-owned forests. The species composition of the herb and moss layer is natural and determines the habitat properties better than the tree-stand or undergrowth. It also gives an account of previous land-use forms and indicates the tendencies of spontaneous vegetation development.

The species composition of secondary coniferous communities in the Glinno Ługi area, significantly differs from that typical of a natural forest (see MATUSZKIEWICZ 2001). These communities found on afforested post-cultivated sandy sites are characterized by a significant share of non-forest species in their flora. Besides numerous psammophilous plants they contain evident field weeds. True forest species (DZWONKO, LOSTER 2001; ZERBE et al. 2007) characteristic of forest communities are absent in the youngest plantations. They appear successively 
along with the ageing of the woodlands (DZwONKO 2001; GóRAS, ORCZEWSKA 2009). Moreover, they are present in the patches with young pine tree stand, where the logging area was artificially re-afforested. The persistence of forest land use is one of the main factors determining the occurrence of forest indicator species (Honnay et al. 1999; DZWONKO, LOSTER 2001; MAJCHROWSKA, WOZIWOdA 2009). The rate of natural succession of coniferous forest vegetation on abandoned arable fields is indicated by the habitat properties as well as by the age of the trees in the neighbouring woodlands (availability of the seeds; GRASHOF-BOKDAM, GEERTSEMA 1998; GRINN-GOFROŃ 2004; KOPRYK et al. 2004).

The final species composition and structure of anthropogenic forest communities significantly depend on human activity and procedures related to forest management (ZERBE et al. 2007). Special attention should be paid to woodlands with a considerable participation of Padus serotina and Quercus rubra. These forest stands should be monitored to observe the development and spread of invasive alien species.

\section{Acknowledgements}

This study has been financially supported by the Polish Ministry of Science and Higher Education within the research project No. N305 091 32/3125 Anthropogenic changes of peat bog plant cover in the River Warta valley near the "Jeziorsko" reservoir.

\section{REFERENCES}

Dzwonko, Z. 2001. Migration of vascular plant species to a recent wood adjoining ancient woodland. Acta Soc. Bot. Pol. 70 (1): 71-77.

DZWONKO, Z., LOSTER, S. 2001. Wskaźnikowe gatunki roślin starych lasów i ich znaczenie dla ochrony przyrody i kartografii roślinności. Typologia zbiorowisk i kartografia roślinności w Polsce. IGiPZ PAN. Pr. Geogr. 178: 119-132.

GóRAS, P., ORCZEWSKA, A. 2009. Species composition of the herb layer of spatially isolated, post-agricultural pine plantations. In: J. HOLEKSA, B. BABCZYŃSKA- 
SENDEK, S. WIKA (eds), The role of geobotany in biodiversity conservation. University of Silesia, Katowice, pp. 89-100.

GORZELAK, A. 1999. Zalesianie terenów porolnych. IBL. Warszawa.

GRASHOF-BOKDAM, C., GEERTSEMA, W. 1998. The effect of isolation and history on colonization patterns of plant species in secondary woodland. J. Biogeogr. 25: 837-846.

GRINN-GOFROŃ, A. 2004. Secondary succession in pine monocultures of abandoned farmlands. In: A. BrZEG, M. WoJTERSKA (eds.), Coniferous forest vegetation differentiation, dynamics and transformations. Wydawnictwo Naukowe UAM, Poznań, Seria Biologia 69, pp. 215-218.

Honnay, O., Hermy, M., Coppin, P. 1999. Effects of area, age and diversity of forest patches in Belgium on plant species richness, and implications for conservation and reforestation. Biol. Conserv. 87: 73-84.

KONDRACKI, J. 2002. Geografia Polski - mezoregiony fizycznogeograficzne. Wydawnictwo Naukowe PWN, Warszawa.

Kopryk, W., Paluch, R., GIL, W. 2004. The possibilities and justification for application of Scots pine natural regeneration on coniferous forest sites. In: A. Brzeg, M. Wojterska (eds.), Coniferous forest vegetation - differentiation, dynamics and transformations. Wydawnictwo Naukowe UAM, Poznań, Seria Biologia 69, pp. 285-291.

MajchrowsKa, A., WoziwodA, B. 2009. Effects of forest history on the biodiversity of vascular plant flora in the Łask Upland (Central Poland). In: J. HoleKsa, B. BABCZYŃSKA-SENDEK, S. WIKA (eds.), The role of geobotany in biodiversity conservation. University of Silesia, Katowice, pp. 165-174.

MAtuszKiewicz, J.M. 2008. Zespoły leśne Polski. Wydawnictwo Naukowe PWN, Warszawa.

MatuszKiewiCZ, W. 2001. Przewodnik do oznaczania zbiorowisk roślinnych Polski. Wydawnictwo Naukowe PWN, Warszawa.

MireK, Z., PięKoŚ-Mirkowa, H., ZajĄC, A., ZAJĄC, M. 2002. Flowering plants and pteridophytes of Poland - a checklist. In: Z. MIREK (ed.), Biodiversity of Poland 1. W. Szafer Insitute of Botany, Polish Academy of Sciences, Kraków. 
OChyra, R., Żarnowiec, J., BednareK-Ochyra, H. 2003. Census catalogue of Polish mosses. In: Z. MIREK (ed.), Biodiversity of Poland 3. W. Szafer Insitute of Botany, Polish Academy of Sciences, Kraków.

SZWEYKOWSKI, J. 2006. An annotated checklist of Polish liverworts and hornworts.

In: Z. MireK (ed.), Biodiversity of Poland 4. W. Szafer Institute of Botany, Polish Academy of Sciences, Kraków.

ZERBE, S. 2002. Restoration of natural broad-leaved woodland in Central Europe on sites with coniferous forest plantations. Forest Ecol. Manage. 167: 27-42.

ZERBE, S., SCHMIDT, I., BETZIN, J. 2007. Indicators for plant species richness in pine (Pinus sylvestris L.) forests of Germany. Biodivers. Conserv. 16: 3301-3316. 